\title{
Microdiagnostics of initial pedogenesis on a phosphogypsum dump
}

\author{
Microdiagnóstico de la edafogénesis inicial en un depósito de fosfoyeso \\ Microdiagnóstico da pedogénese inicial num depósito de fosfogesso
}

\section{AUTHORS}

\section{Belobrov V.P. ${ }^{1, @}$}

belobrovvp@mail.ru

\section{Lebedeva M.P. ${ }^{1}$}

Abrosimov K.N. ${ }^{1}$

\section{Grebennikov}

A.M. ${ }^{1}$

Torochkov E.L. ${ }^{2}$

Ryashko A.I. ${ }^{2}$

@ Corresponding Author

${ }^{1}$ V.V. Dokuchaev Soil Science Institute, Russian Academy of Sciences, per Pyzhevskii 7. Str. 2. 119017 Moscow, Russia.

2 Ya.V. Samoilov Research Institute for Fertilizers and Insectofungicides. 75, Severnoye shosse. 162622 Cherepovets, Russia. 
pela presença de raízes vivas de gramineas e musgos, que é característica de uma crosta biogénica. As duas partes da crosta foram caracterizadas às escalas macro e micro através de lâminas delgadas e imagens tomográficas. A presença de características de bumificação e porosidade observadas no interior da crosta permitiram o diagnóstico da pedogénese inicial.

\section{Introduction}

Soils of arid, semidesert and desert regions are characterised by the formation of surface crust, which is well studied at a macro- and micro-scale (Gerasimov 1954; Atkinson 1979; Pagliai and LaMarca 1979; Figuera 1984; Allen 1985; Bouza and Del Valle 1993; Pagliai 1994; Mees and Singer 2006; Pagliai 2008; Briggs and Morgan 2008; Dixon 2009). The crust can be formed on different substrates, both natural and technogenic (Androkhanov et al. 2000; Gerasimova et al. 2003; Goleusov and Lisetskii 2005; Fox et al. 2009; Mees and Tursina 2010; Pagliai and Stoops 2010; Uzarowicz and Skiba 2011). Initial soil-forming processes on technogenic substrates, such as phosphogypsum, are the least studied topic. The phosphogypsum substrate has a very acidic reaction in solution $(\mathrm{pH}$ 3.4-3.6), which is the main obstacle to its colonization by plants and the development of soil.

In Russia, the first studies on bioremediation of phosphogypsum dumps were conducted at the Balakov Affiliation of the "Apatit" Joint-Stock Company (Lubimova and Borisochkina 2007; Belobrov et al. 2014). This company has been producing phosphate fertilizers for many decades. Phosphogypsum is generated as a by-product of treating phosphate ore with sulphuric acid during fertilizer production. Some parts of the dumps are being continuously built up by new additions of phosphogypsum, whereas the other parts have remained undisturbed for a long period of time and have gradually become colonised by explerents- soil algae and ruderal plants.

The purpose of this work is to study the features of soil formation on such an extremely unique object as the acid substrate of phosphogypsum dumps with the use of micromorphological and microtomographic methods.

\section{Material and Methods}

\subsection{Study area}

The study area is situated at the south-facing slopes of a phosphogypsum dump, which have remained undisturbed for a period of 20 to 30 years. The dump location is $20 \mathrm{~km}$ from the town of Balakovo in the Saratov Region (Figure 1), which is within the dry steppe zone of southern Russia. The phosphogypsum waste accumulated over that period of time has 
covered more than a hundred hectares of Calcic Chernozems (IUSS Working Group WRB 2014). These Calcic Chernozems around the phosphogypsum dump have a weakly alkaline $\mathrm{pH}(7.7)$, high exchangeable potassium (450 ppm/kg) and moderate mobile phosphorus (220 ppm/kg).

The study area is characterized (according to the nearest meteorological Station in Pugachev town) by a mean air annual temperature of $4.8^{\circ} \mathrm{C}$ $\left(-13,3^{\circ} \mathrm{C}\right.$ in January, $+22^{\circ} \mathrm{C}$, in July), a mean annual precipitation of $450 \mathrm{~mm}$, a mean annual temperature of $-19^{\circ} \mathrm{C}$ at the soil surface in January and $+47^{\circ}{ }^{\circ} \mathrm{C}$ in July (minimum $-46^{\circ} \mathrm{C}$, maximum $\left.+63^{\circ} \mathrm{C}\right)$. In winter, the anticyclone state of the atmosphere with very low temperatures predominates, causing the freezing of phosphogypsum dumps and surrounding Chernozems to a depth of $50 \mathrm{~cm}$ (Environmental Protection in Russia 2010). Together these climatic para- meters are characteristic of a dry continental climate with drought periods that create extreme conditions for soil biota.

The phosphogypsum dumps serve as an artificial substrate for colonization, firstly, by soil algae and then, if left undisturbed, mostly by liverworts (Marchantiophyta) (Figures 2-4) and slim-stem small reed grass (Calamagrostis neglecta P.B.) (Figures 5,6), the latter being the dominant higher plant capable of surviving on this substrate (Gusev 2006; Belobrov et al. 2016). Natural pedogenetic processes on the old dump slopes with inclinations of $30-40^{\circ}$ result in the formation of the crust 2-3 cm thick (Figures 5-7); thicker crusts are formed along runoff hollows on south-facing slopes (Figure 3 ). To analyse the evidence of initial pedogenesis, the crust was sampled at a south-facing slope of the old (2030 years) phosphogypsum dump (Figure 5).

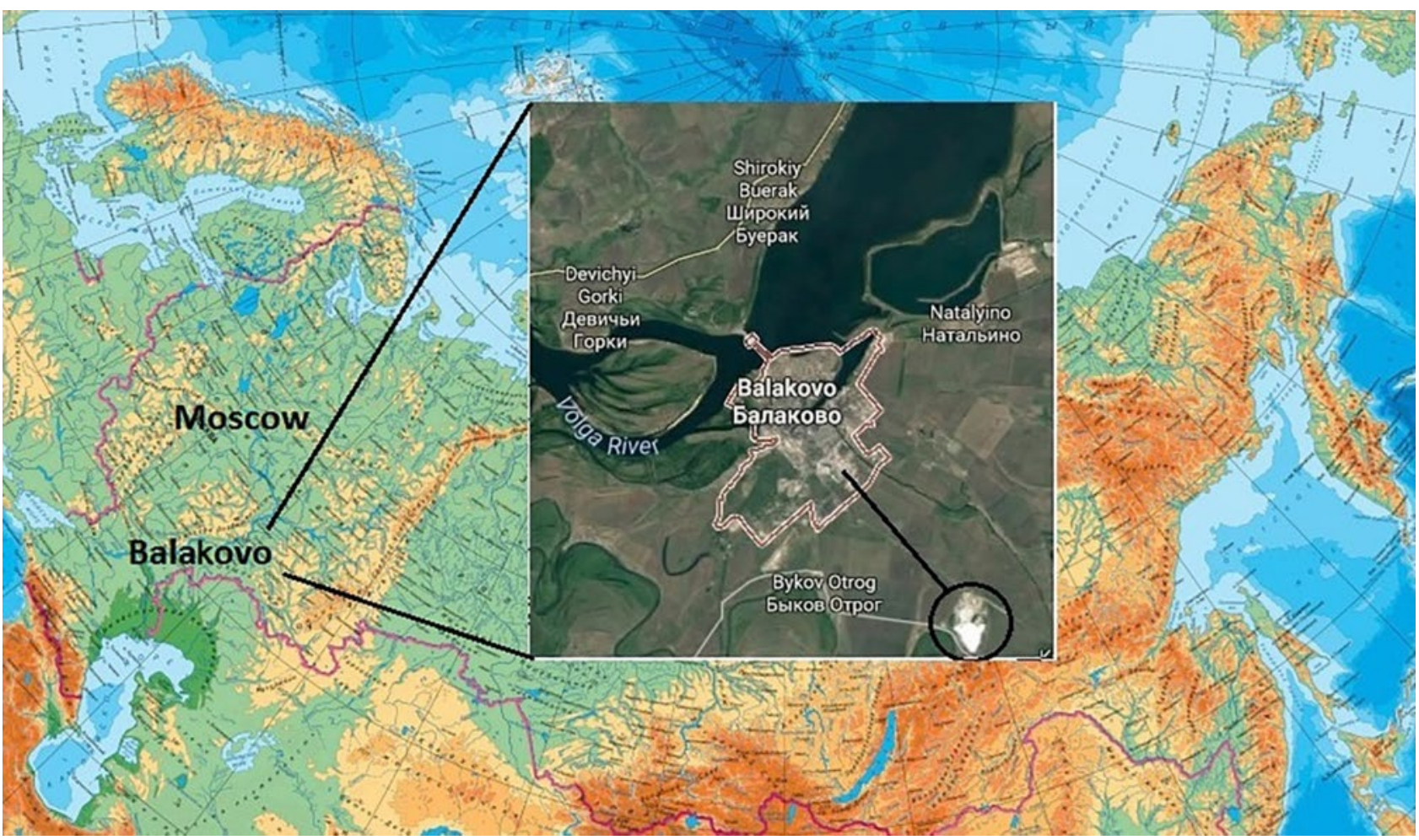

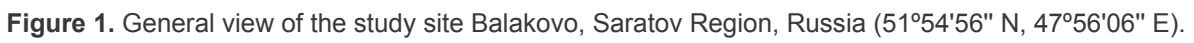




\subsection{Laboratory analyses}

The agrochemical analyses were carried out in the Laboratory of the V.V. Dokuchaev Soil Science Institute according to standard techniques generally accepted in Russia (Vorob'eva 1998). The exchangeable potassium content of the fresh phosphogypsum was measured according to the Maslova method, which involved potassium $\left(\mathrm{K}_{2} \mathrm{O}\right)$ extraction from soil by ammonium acetate $\left(\mathrm{CH}_{3} \mathrm{COONH}_{4}\right)$ solution with $1 \mathrm{~mol} / \mathrm{dm}^{3}$ concentration and soil:solution ratio of $1: 10$, followed by measurement of the potassium content in the extract using a flame photometer. The mobile phosphorus content was determined by the Kirsanov method for acidic soils, which involves the extraction of available phosphorus $\left(\mathrm{P}_{2} \mathrm{O}_{5}\right)$ from soil by hydrochloric acid solution with $0.2 \mathrm{~mol} / \mathrm{dm}^{3}$ concentration, followed by measurement of the phosphorus content using a photoelectrocolorimeter. The $\mathrm{pH}$ of the water suspension was determined using a potentiometric method with a soil to water ratio of 1:2.5.

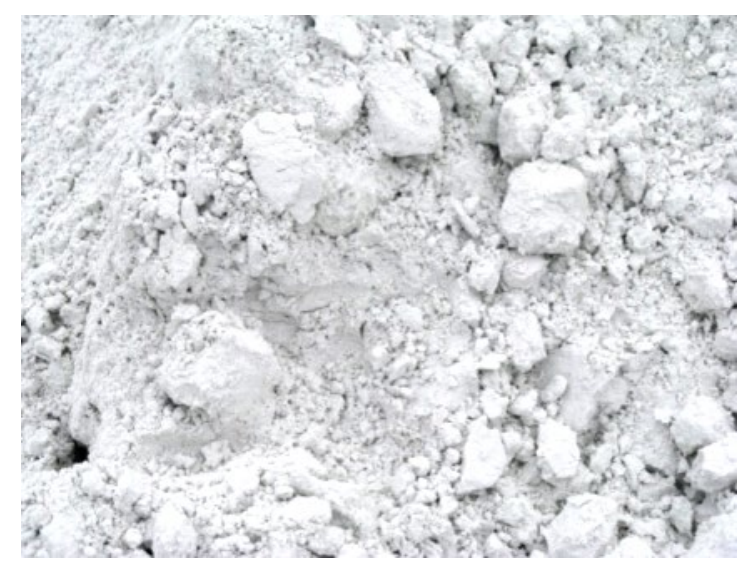

Figure 2. Freshly dumped phosphogypsum.

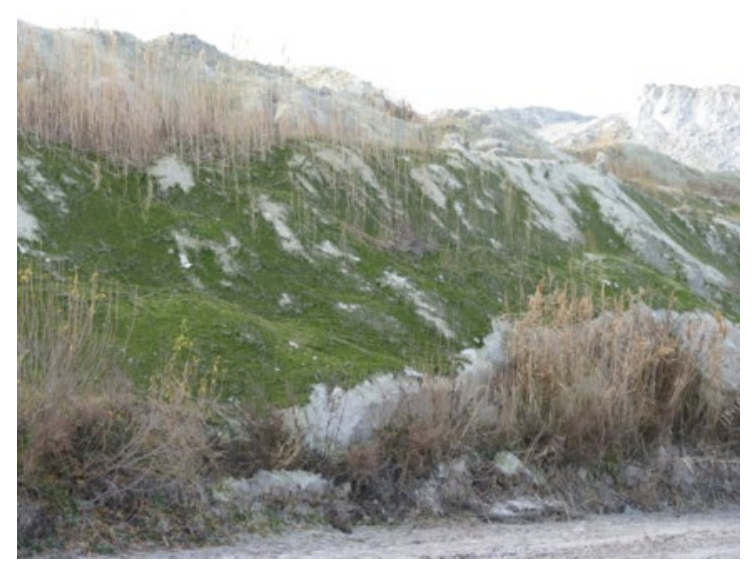

Figure 4. The north-facing slope.
Phosphogypsum samples from the fresh and old dump surfaces were analysed by microtomographic and micromorphological methods. The analysis of microporosity was conducted using a SkyScan 1172 tomographic scanner at resolutions of 8.75 and $13.46 \mu \mathrm{m}$ per pixel (for fresh phosphogypsum and the crust horizon, respectively) and followed by $3 \mathrm{D}$ reconstruction using a CTvox and Ctan Programme and scanned images of 2D horizontal cross-sections of the sample.

The thin sections (30 $\mu \mathrm{m}$ thick) were prepared by M.A. Lebedev (at V.V. Dokuchaev Soil Science Institute) from undisturbed soil samples of every horizon, and impregnated with a Cristal MC-40 resin at room temperature. The micromorphological observations were carried out using an Olympus BX51 TL RL Polmicroscope and an Olympus DP25 digital camera. under planar and cross-polarized light. The description was according to Stoops (2003).

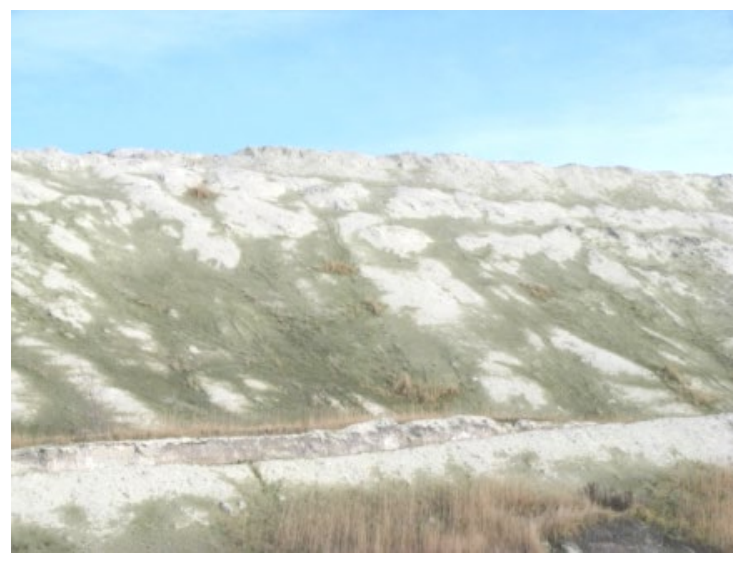

Figure 3. The south-facing slope.

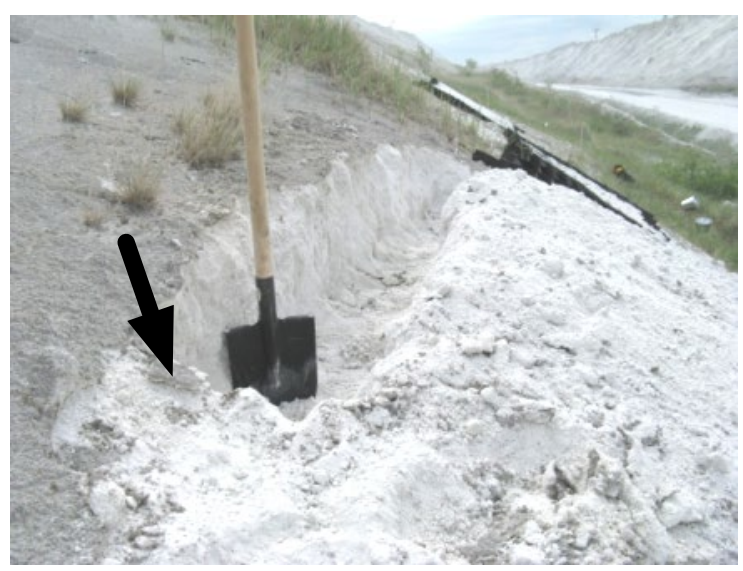

Figure 5. Arrow indicating a sampling point at the southfacing slope. 


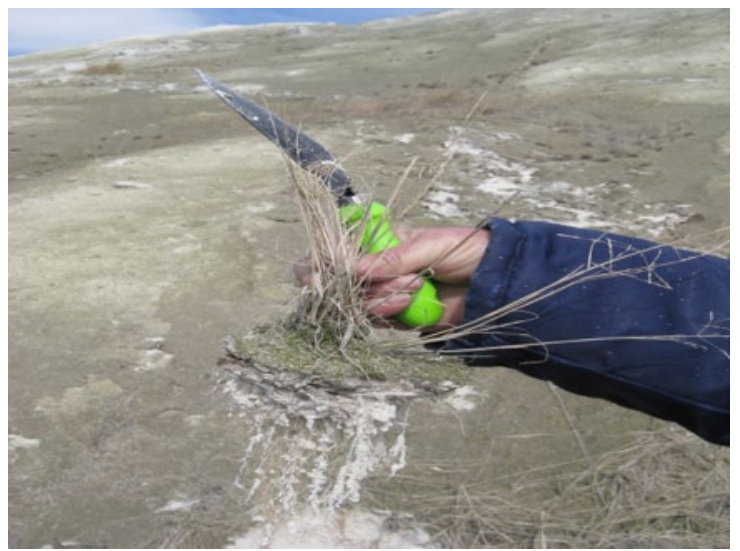

Figure 6. The crust with the reed grass.

\section{Results and Discussion}

\subsection{Macromorphological features}

The fresh phosphogypsum is white, with a very fragile crumb-cloddy structure that is friable ( $\mathrm{Fi}-$ gure 2). After a short period of time (1-2 years) phosphogypsum undergoes natural compaction and cementation and acquires a massive structure. The old phosphogypsum dump surface in its undisturbed state has a crust $2-3 \mathrm{~cm}$ thick (Figures 5-7). The crust consists of two parts: 1) an upper part that is up to $2 \mathrm{~cm}$ thick, distinguished in the field by a darker (greyish) colour, micro-lamination and firm consistency and 2) a lower part, about $1 \mathrm{~cm}$ thick, which is characterized by a lighter colour and a looser consistency and weak cloddy structure. The lower part of the crust is underlain by pure, very dense, white phosphogypsum. Together both the upper and lower parts constitute a biogenic crust with its structural organisation being predetermined

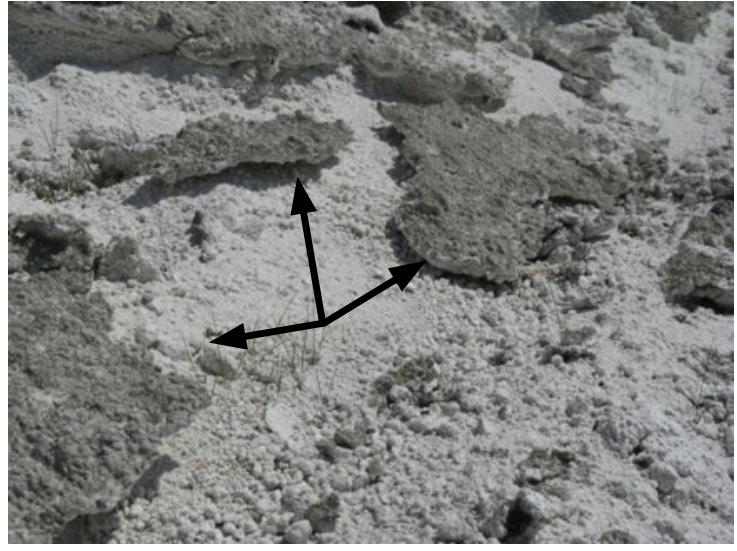

Figure 7. A degraded crust on an old dump of phosphogypsum.

mainly by the presence of live roots of grasses and mosses (Malam et al. 1999). The crust is held together by the root systems of slim-stem small reed grass and protected by the cover of mosses and lichens.

\subsection{Agrochemical characteristics}

The soil crust was shown to have dramatically different agrochemical properties in comparison to those of fresh phosphogypsum (Table 1). Fresh phosphogypsum is very acidic, while the crust has a neutral $\mathrm{pH}$, which decreases with depth and becomes equal to that of fresh phosphogypsum at a depth of $60-70 \mathrm{~cm}$. A neutral $\mathrm{pH}$ within the 20-cm-thick layer at the surface of the dump allows for its colonization by mosses and site-specific grasses (Samkov et al 1989; Gusev 2006). The neutral $\mathrm{pH}$ is likely to result from two processes: 1) deflation (wind erosion) of neighbouring Chernozems with aeolian deposition of their particles onto the phosphogypsum surface and 2) a gradual leaching of residual acids from

Table 1. The values of $\mathrm{pH}, \mathrm{P}_{2} \mathrm{O}_{5}$ and $\mathrm{K}_{2} \mathrm{O}$ in fresh phosphogypsum and the crust

\begin{tabular}{|c|c|c|c|c|}
\hline \multirow{2}{*}{ Samples } & \multirow{2}{*}{ Depth, cm } & \multirow{2}{*}{ pH } & $P_{2} O_{5}$ & $\mathrm{~K}_{2} \mathrm{O}$ \\
\hline & & & \multicolumn{2}{|c|}{$p p m / k g$} \\
\hline Fresh phosphogypsum & $0-3$ & 3.6 & 1020 & 520 \\
\hline Crust & $0-3$ & 6.9 & 3030 & 40 \\
\hline \multirow{3}{*}{ Layers under the crust } & $10-20$ & 6.3 & not det. & not det. \\
\hline & $20-40$ & 4.7 & not det. & not det. \\
\hline & $60-70$ & 4.6 & not det. & not det. \\
\hline
\end{tabular}


phosphogypsum by atmospheric precipitation. There are tendencies for an increase in the mobile (available) phosphorus content and a sharp decrease in the potassium content within the crust.

\subsection{Micromorphological features}

We have identified microparts within the initial soil crust, where original phosphogypsum undergoes structural change with the formation of crumb and fine platy aggregates (Figures 8AD). The microfabric heterogeneity and differences in the character of porosity are caused, in our opinion, by different densities and depths of root systems of plants and rhizoids of mosses. Remains of moss filaments can be seen inside the angular blocky aggregates as well as at their surface, where organic hypocoatings are formed. The most open and delicate (open-work) porosity within the upper parts of biogenic crust is associated with interlacing of half-decomposed moss filaments at the top of the crust (Figure $8 \mathrm{~B}$ ). The lower parts of the crust with fine platy microstructure has a stronger impregnation by dark brown amorphous organic matter with a banded distribution, which is probably due to cryogenic differentiation of substances during seasonal freezing under the continental climate of conditions the study area (Figures 8E, F). The lower part of the crust consists of densely packed acicular (needle-like) crystals of gypsum and anhydrite (the latter has formed in the course of thin section preparation). The absence of signs of cryogenic sorting of the groundmass in the upper layer of the crust is associated with its drier state - in winter due to the blowing of snow from the frozen surface and in the summer of lateral movement of rainfall.

We suggest that numerous dark concentrations and cells within phosphogypsum material are indicative of the initial stages of microbiogenic co-

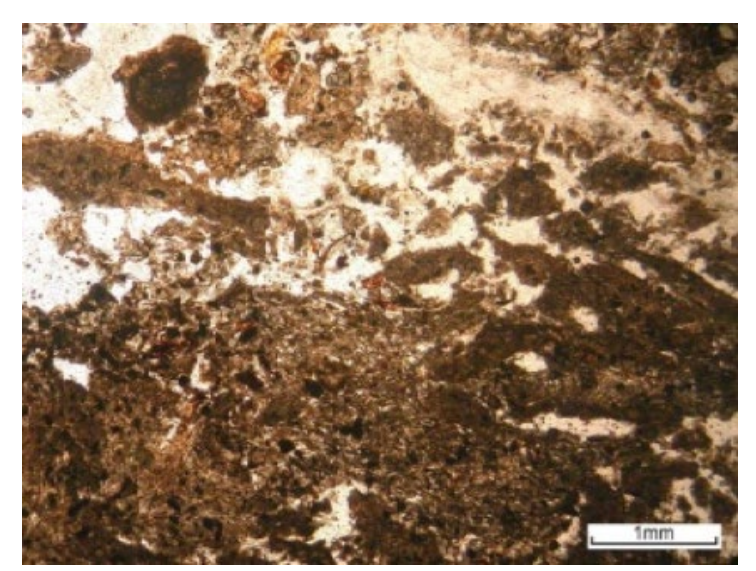

A

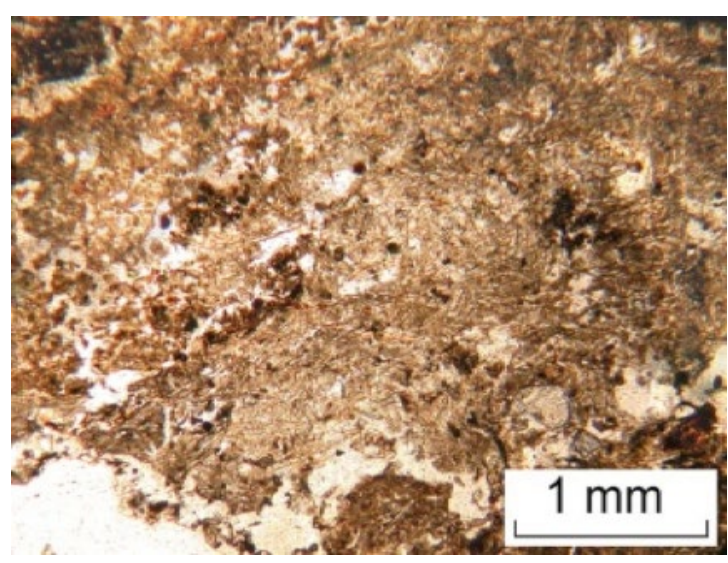

C

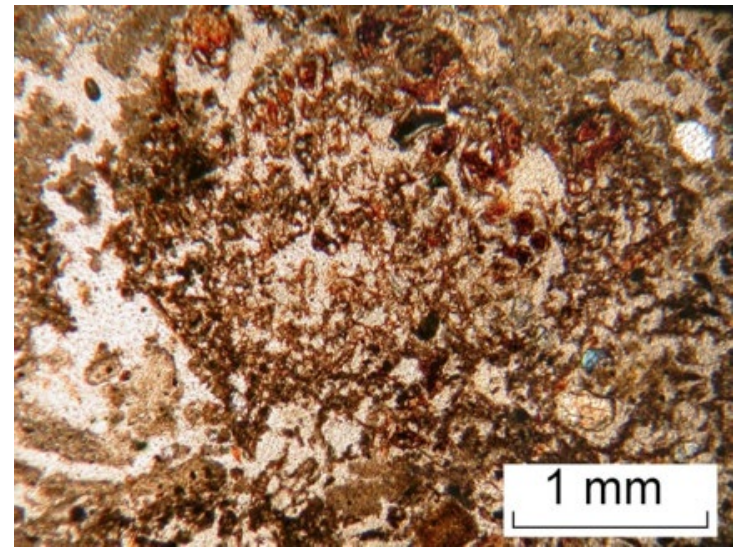

B

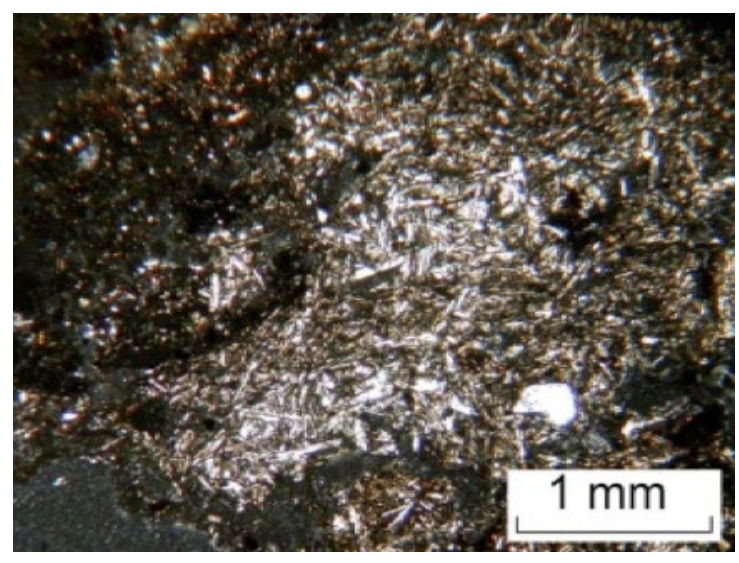

D 


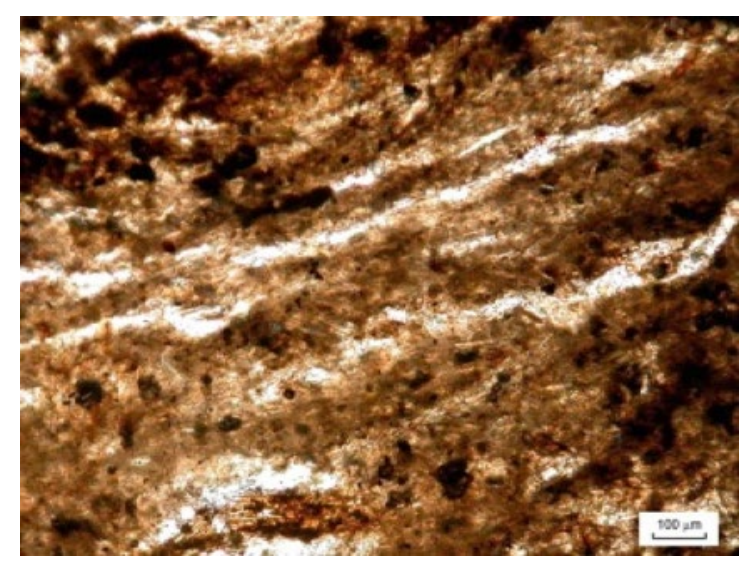

$\mathrm{E}$

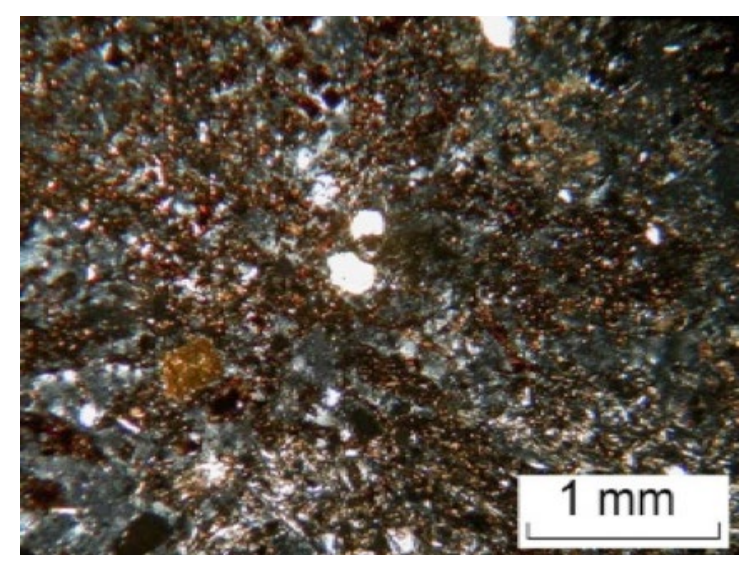

G

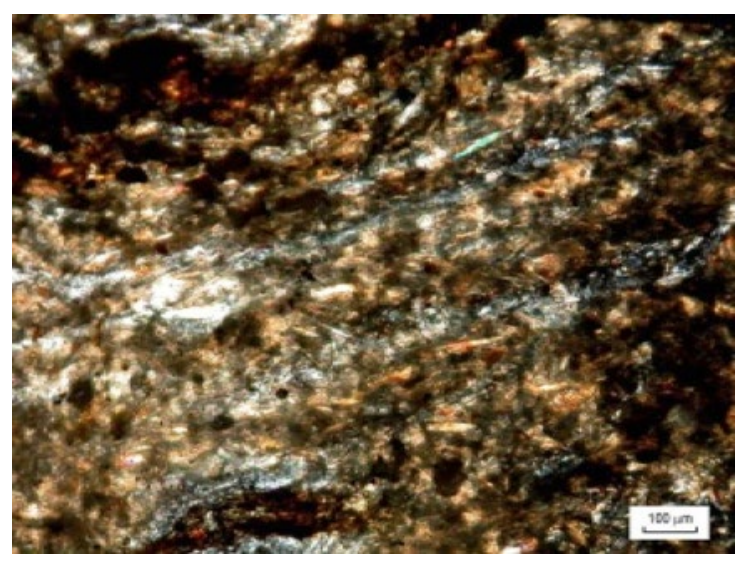

$\mathrm{F}$

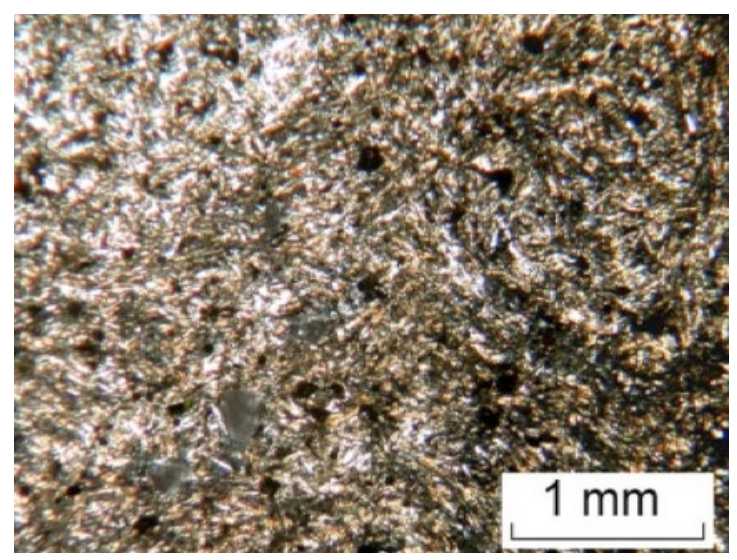

$\mathrm{H}$

Figure 8. Microphotographs illustrating the pedogenic processes on a phosphogypsum dump: A) A combination of platy and crumb microstructures and thin acicular gypsum crystals $(0-2 \mathrm{~cm}, \mathrm{PPL}) ; \mathrm{B})$ The microzone with an open porosity resulting from interlacing of half-decomposed moss filaments and rhizoids (0-2 cm, PPL); C) A non-uniform impregnation of compacted crystalline gypsum by amorphous organic fine material and small concentrations of the organic matter in pores $(0-2 \mathrm{~cm})$ - PPL D) - same in XPL; E) Banded distribution of polymorphic organic matter with an irregular distribution of charcoal particles (2-4 $\mathrm{cm}$ ) - PPL; F) - same in XPL; G) A porous mass of small acicular gypsum crystals non-uniformly impregnated by isotropic organic matter, with inclusions of fine-sand sized quartz grains and calcareous concentrations. The microzone with a high content of organic matter $(4-5 \mathrm{~cm})-\mathrm{XPL} ; \mathrm{H})$ the microzone of almost pure phosphogypsum with isolated pores - XPL.

Ionisation (Figures 8G, H). The organic material maximum occurs in the lower crust layer, not in the upper crust. We assume that the maximum amount of organic matter in the lower part of the crust is due to its local more favorable living conditions of the biota (more moisture) under the "roof" by a stronger and dry upper layer of the crust.

The groundmass of the crust horizon formed at the phosphogypsum dump surface consists mainly of acicular gypsum microcrystals, which are typical for horizons of arid soils containing flour-like gypsum (Poch et al. 2010). Biogenic compounds clearly identified by micromorphological observations play a key part in the crumb microstructure development and the organic matter accumulation within the biogenic crust. According to the classification by Belnap and Eldridge (Belnap et al. 2001), the crusts studied can be attributed to hypermorphic biogenic crusts dominated by epidaphic microorganisms (living mostly at the surface) and various bryophyte species (e.g., liverworts). 


\subsection{Microtomographic analysis}

\subsubsection{The structure of fresh phosphogypsum}

The fresh phosphogypsum consists of numerous white, sharp-edged, rectangular and rhomboidal grains, up to $100 \mu \mathrm{m}$ in size, forming loose crumb aggregates (Figure 9). The central part of the analysed sample is denser and has layered features. There are two types of microporosity: 1) numerous non-connected elongated or rounded pores from 50 to $200 \mu \mathrm{m}$ long and 2) fissure-like pores variable in length and 50$80 \mu \mathrm{m}$ in width. There are inclusions and compacted features inside the studied sample. The inclusions have an irregular distribution, white colour and elongated shape. Most of them have sizes of 100-150 $\mu \mathrm{m}$, with rarer larger (150-350 $\mu \mathrm{m})$ inclusions and extremely rare very large (1500-2000 $\mu \mathrm{m}$ ) inclusions (Figures 9, 10).

The arrows in Figures 9,10, 11, 12 show different structural elements: red - pores of various types, including those filled with phosphogypsum; yellow - aggregates of phosphogypsum; green - mineral grains.

\subsubsection{The structure of the soil crust (on the old phosphogypsum dump)}

The upper part $(1-1.2 \mathrm{~cm})$ of the soil crust is the most porous and structured, with gypsum crystals masked by the organic matter. Being

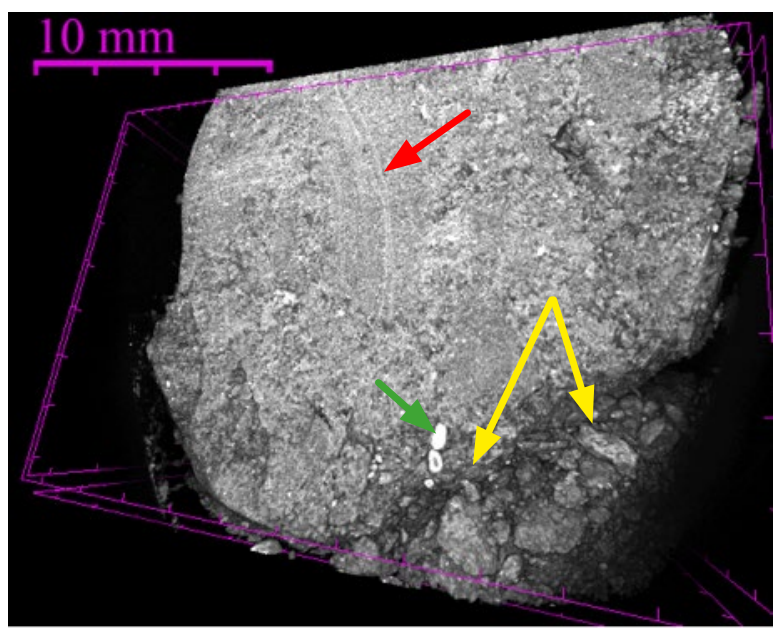

Figure 9. Fresh phosphogypsum, cross-section. defined as amorphous in the course of micromorphological observations, the organic matter strongly (almost completely within some microzones) impregnates the original phosphogypsum material (Figure 11). The lower part of the soil crust on phosphogypsum has fewer pedogenic features, higher density and numerous platy and prism-like fragments with sharp edges and sizes from 200 to $1500 \mu \mathrm{m}$. The upper (organic) part is separated from phosphogypsum parent material by a distinct transitional microhorizon, which contains vertically elongated structural units resembling pores, filled with fine-textured phosphogypsum material.

The upper part of the crust (Figure 11A) is characterized by enrichment with amorphous organic fine material. In its lower part, the banded distribution of this material is particularly clearly seen, which we observed in the thin sections (Figure 8E). In the lower layer of the crust (Figure 11B), the distribution of the organic matter is microzonal, which was also recorded at the microlevel in the thin sections from this layer (Figures $8 \mathrm{G}, \mathrm{H}$ ).

\subsubsection{Types of porosity and inclusions within the soil crust}

Large round pores up to $2000 \mu \mathrm{m}$ in diameter occur only within the upper part of the crust. Few smaller $(100-250 \mu \mathrm{m})$ round pores are found in the upper and transitional microhorizons. Nume-

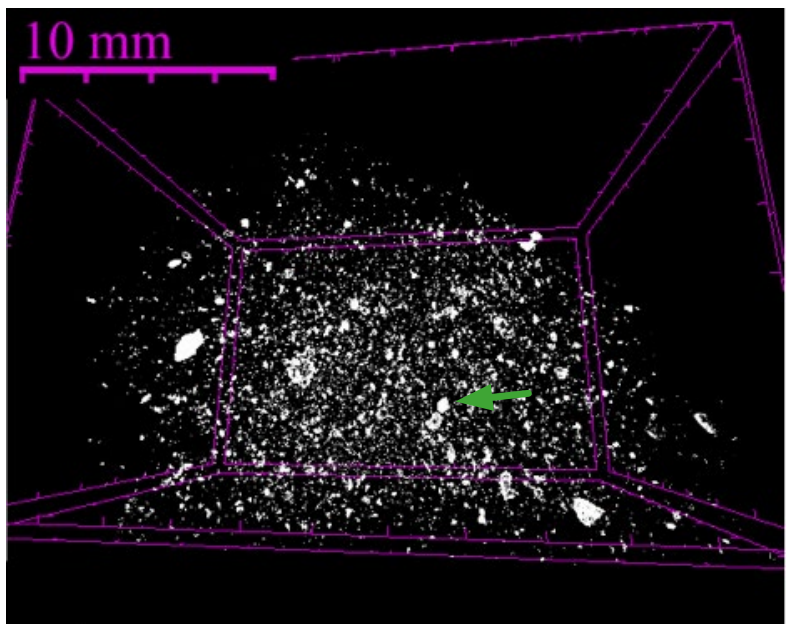

Figure 10. Inclusions and compacted features within a fresh phosphogypsum sample. 


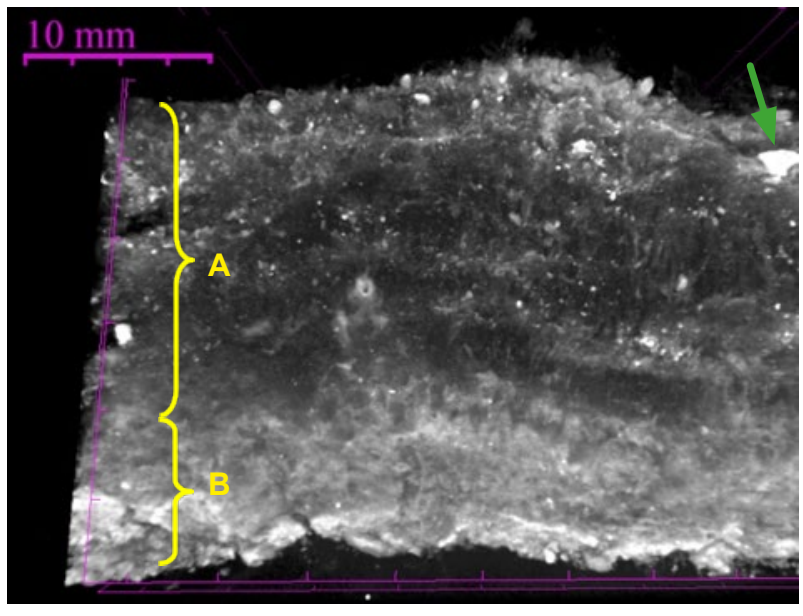

Figure 11. Cross-section through the crust.

rous pores-fissures of varied thickness are distributed over the whole volume of the crust, but are most developed in its lower part, especially, at the contact with phosphogypsum parent material. All the microhorizons contain inclusions (Figure 12). Large $(1500 \mu \mathrm{m})$ inclusions dominate within the upper microhorizon, medium $(300 \mu \mathrm{m})$ inclusions prevail within the transitional microhorizon and small $(50 \mu \mathrm{m})$ inclusions - within the lower microhorizon.

Thus, the results of microtomographic analysis demonstrate a vertical differentiation of features within the soil crust formed on phosphogypsum, which is in good agreement with the microstructure analysis data (Belobrov at el. 2014; Belobrov at el. 2016).

\section{Conclusions}

(1) The macro-and micromorphological diagnostics and microtomographic analysis of the crust at the surface of the old phosphogypsum dump allowed for the description of the early stages of pedogenesis - the formation of the initial soil crust, which consists of two parts: an upper part up to $2 \mathrm{~cm}$ thick and a lower part about $1 \mathrm{~cm}$ thick. The crust has features of a strong

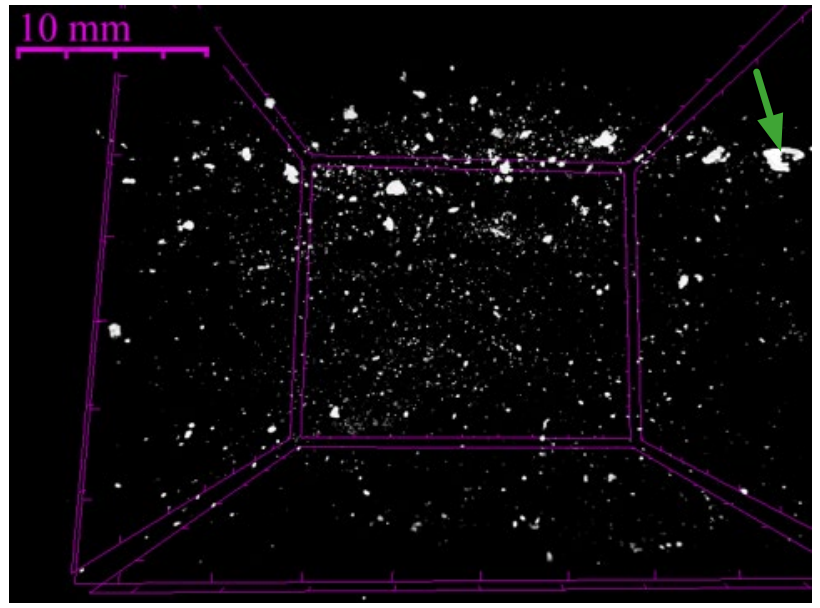

Figure 12. Inclusions and compacted features within the crust horizon sample.

impregnation by organo-mineral matter and, presumably, indications of cryogenic differentiation of amorphous compounds as a result of seasonal freezing, since the background soils and the phosphogypsum dump freezes to 50 $\mathrm{cm}$.

(2) The evolution from fresh phosphogypsum to soil crust is a gradual process that takes at least 20-30 years, as no such crusts have been found during observations of younger phosphogypsum surfaces on the same dump. The main factor controlling the rates of initial pedogenesis and the crust formation is the moisture regime at the surface of the phosphogypsum dump - the upper dense layer of the crust retains the lower part from the strong and quick drying. The higher the moisture, the thicker the moss cover and the more diverse is the community of higher plants.

(3) Biogenic structuring plays a key part in the initial pedogenesis and leads to the formation of a crumb structure and the accumulation of amorphous organic matter. The microzonality of the soil material is caused by an irregular distribution of roots of higher plants and rhizoids of mosses and different rates of their decomposition in the course of humification process. 


\section{Acknowledgements}

Microstructural research was supported by grant of the Presidium of the Russian Academy of Sciences: "Theoretical and experimental research for effective scientific and technological development of the agro-industrial complex of the Russian Federation" (2018-2020).

\section{REFERENCES}

-Allen BL. 1985. Micromorphology of Aridisols. In: Douglas LA, Thompson ML, editors. Soil Micromorphology and Soil Classification. Madison: Soil Science Society of America Publ. p. 197-217.

- Androkhanov BA, Ovsyannikova CB, Kurachev BB. 2000. Technozems: Properties, Regime, Function. Novosibirsk. Nauka (in Russian).

- Atkinson K. 1979. Morphology and mineralogy of Red Desert soil in the Libyan Sahara. Earth Surface Processes 4:103-115.

- Belnap J, Rosentreter R, Leonard S, Kaltenecker JH, Williams J, Eldridge D. 2001. Biological Soil Crusts: Ecology and Management. Materials Distribution Center. Denver, Colorado, USA: Department of Interior, Bureau of Land Management.

- Belobrov VP, Lebedeva MP, Grebennikov AM, Torochkov EL, Ryashko Al, Lebedev MI. 2016. Micromorphological diagnostics of biogenic crusts and microhorizons of initial pedogenesis on phosphogypsum dump. In: Abstracts of the 15th International Conference on Soil Micromorphology; 2016 Nov 27-Dec 5; Mexico City, Mexico; p. 16-17.

- Belobrov VP, Lubimova IN, Grebennikov AM, LebedevaVerba MP, Lebedev MA, Abrosimov KN, Kulenkamp AYU, Riashko Al. 2014. Microporosity and Microstructure of Phosphogypsum. Moscow: NIUIF. p. 511-515 (in Russian).

- Bouza P, Del Valle HF. 1993. Micromorphological, physical and chemical characteristics of soil crust types of the Central Patagonia Region, Argentina. J Native Agricultural Envir. 7(4):355-368.
- Briggs A, Morgan JW. 2008. Morphological diversity and abundance of biological soil crusts differ in relation to landscape setting and vegetation type. Aust $\mathrm{J}$ Bot. $56: 246-253$

- Dixon JC. 2009. Aridic soils, patterned ground, and desert pavements. In: Parsons AJ, Abrahams AD, editors. Geomorphology of Desert Environments. Netherlands: Springer. p. 101-120.

- Environmental Protection in Russia. 2010. Statistical Yearbook Moscow. Rosstat Publ. 303 p. (in Russian).

- Figuera HL. 1984. Horizonte vesicular: morfologia y genesis en un aridisol del norte de la patagonia. Ciencia del Suelo 2:121-129.

- Fox SJ, Mills AJ, Poch RM. 2009. Micromorphology of surface crusts in the Knersvlakte, South Africa. Journal of Mountain Science 6(2):189-196.

- Gerasimov IP. 1954. The features of similarity and difference in the nature of deserts. Priroda 2:11-22 (in Russian).

- Gerasimova MI, Stroganova MN, Mozharova NV, Prokofieva TV. 2003. Anthropogenic Soils (Genesis, Geography, Reclamation). Moscow: Moskow University (in Russian).

- Goleusov PV, Lisetskii FN. 2005. Reproduction of Soils in Anthropogenic Landscapes of the Forest-Steppe. Belgorod: Belgorod national University (in Russian).

- Gusev AP. 2006. Primary succession on dumps of phosphogypsum (Gomel chemical factory, Belarus). Ecologia 3:232-235 (in Russian).

- IUSS Working Group WRB. 2014. World Reference Base for Soil Resources 2014. International soil classification system for naming soils and creating legends for soil maps. World Soil Resources Reports No. 106. Rome: FAO.

- Lubimova IN, Borisochkina TI. 2007. The Effect of Potentially Hazardous Chemical Elements Contained in Phosphogypsum in the Environment. Moscow: V.V. Dokuchaev Soil Science Institute (in Russian).

Malam IO, Trichet J, Défarge C, Couté A, Valentin C. 1999. Morphology and microstructure of microbiotic soil crusts on a Tiger Bush sequence (Niger, Sahel). Catena 37:175-196.

- Mees F, Singer A. 2006. Surface crusts on soils/ sediments of the southern Aral Sea basin, Uzbekistan. Geoderma 136:152-159.

- Mees F, Tursina TV. 2010. Salt minerals in saline soils and salt crusts. In: Stoops G, Marcelino V, Mees F, editors. Interpretation of Micromorphological Features of Soils and Regoliths. Amsterdam: Elsevier. p. 441-469.

- Pagliai M. 1994. Micromorphology and soil management. Developments in Soil Science, vol. 22. Amsterdam: Elsevier. p. 623-640. 
- Pagliai M. 2008. Crusts, crusting. In: Chesworth W, editor. Encyclopedia of Soil Science. Hidelberg: Springer. p. 171-179.

- Pagliai M, La Marca M. 1979. Micromorphological study of soil crust. Agrochimica 23:16-25.

- Pagliai M, Stoops G. 2010. Physical and biological surface crusts and seals. In: Stoops G, Marcelino V, Mees $F$, editors. Interpretation of Micromorphological Features of Soils and Regoliths. Amsterdam: Elsevier. p. 419-440.

- Poch RM, Artieda O, Herrero J, Verba-Lebedeva M. 2010. Gypsic features. In: Stoops G, Marcelino V, Mees $F$, editors. Interpretetion of Micromorphological Features of Soils and Regoliths. Chapter 10. Amsterdam: Elsevier. p. 195-216.

- Samkov YUE, Ogievskii DV, Pardaev TA. 1989. About the Natural Overgrowing of the Tailings Dumps of the "Phosphorite" Association. Study, Protection and Rational Use of Natural Resources. Ufa: Bashkir Scientific Center, Ural branch Academy of Sciences of the USSR (in Russian).

- Stoops G. 2003. Guidelines for Analysis and Description of Soil and Regolith Thin Sections. Madison, WI: Soil Science Society of America.184 p.

- Uzarowicz Ł, Skiba S. 2011. Technogenic soils developed on mine spoils containing iron sulphides: Mineral transformations as an indicator of pedogenesis. Geoderma 163:95-108.

- Vorob'eva LA. 1998. Chemical Analysis of Soils. Moscow: Moskow University (in Russian). 